NIPER-570

(DE92001040)

Hydrodenitrogenation: An Increasingly Important Part of Catalytic Hydroprocessing Interlocking of Thermodynamics and Kinetics

By

W. V. Steele

R. D. Chirico

April 1992

Performed Under Cooperative Agreement No. DE-FC22-83FE60149

IIT Research Institute

National Institute for Petroleum and Energy Research

Bartlesville, Oklahoma

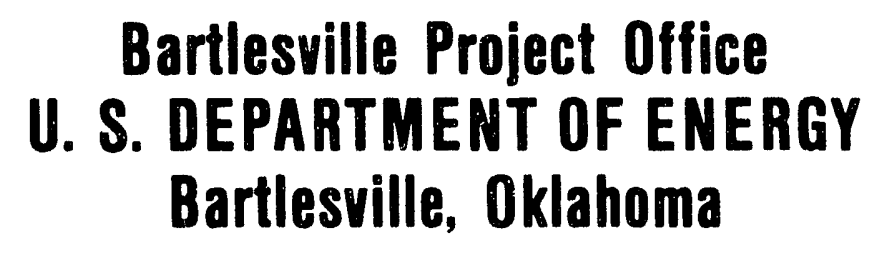




\section{DISCLAIMER}

This report was prepared as an account of work sponsored by an agency of the United States Government. Neither the United States Government nor any agency thereof, nor any of their employees, makes any warranty, express or implied, or assumes any legal liability or responsibility for the accuracy. completeness, or usefulness of any information, apparatus, product, or process disclosed, or represents that its use would not intringe privately owned rights. Reference herein to any specific commercial product process, or service by trade name, trademark, manufacturer, or otherwise does not necessarily constitute or imply its endorsement, recommendation, or favoring by the United States Government or any agency thereo'. The views and opinions of authors expressed herein do not necessarily state or reflect those of the United States Government or any agency thereof.

This report has been reproduced directly from the best available copy.

Available to DOE and DOE contractors from the Office of Scientific and Technical Information, P.O. Box 62, Oak Ridge, TN 37831; prices available from (615)576-8401, FTS 626-8401.

Available to the public from the National Technical Information Service, U.S. Department of Commerce, 5285 Port Royal Rd., Springfield, VA 22161. 
NIPER-570

Distribution Category UC-125

Hydrodenitrogenation: An Increasingly Important Part of Catalytic NIPER- -570 Hydroprocessing Interlocking of Thermodynamics and Kinetics DE92 001040

Topical Report
By
W. V. Steele
R. D. Chirico

April 1992

Work Performed Under Cooperative Agreement No. FC22-83FE60149

Prepared for

U.S. Department of Energy

Assistant Secretary for Fossil Energy

\author{
W. D. Peters, Project Manager \\ Bartlesville Project Office \\ P. O. Box 1398 \\ Bartlesville, OK 74005
}

Prepared by

IIT Research Institute

National Institute for Petroleum and Energy Research

P. O. Box 2128

Bartlesville, OK 74005 


\section{EXECUTIVE SUMMARY}

Hydrogen management will be a critical issue for refiners as a result of the 1990 Amendments to the U.S. Clean Air Act. The problem stems from a reduction in hydrogen production and an increase in consumption. The addition of oxygenates to gasoline, as mandated for certain geographic areas at certain times of the year, will mean that less octane is required from the reformer lowering the severity of its operation and hence the amount of hydrogen formed. Also the mandate reducing aromatics content to less than 20 per cent will result in a further reduction of reformer operating severity, hence severely reducing hydrogen production. Another contribution to the problem in managing hydrogen results from increased hydrogen consumption to meet benzene specifications, reduced T90, and lower sulfur levels in diesel. To exacerbate the problem, as heavier crudes are introduced to the refinery, the importance of catalytic hydroprocessing will increase. Hydroprocessing can be a hydrogen guzzler.

Catalytic hydrodenitrogenation (HDN) is a key step in hydroprocessing heavy petroleum. Using sulfided transition metal catalysts organic nitrogen and sulfur are commonly removed via reaction at 300 to $400^{\circ} \mathrm{C}$ and 75 to $150 \mathrm{~atm}$. of hydrogen. Under these severe conditions, hydrogen is consumed not only in breaking carbonnitrogen and carbon-sulfur bonds, but also in saturating aromatic components in the feed. Hydrogen consumption in excess of $1500 \mathrm{scf} / \mathrm{bbl}$ (standard cubic feet per barrel) is common in hydrotreating feedstocks containing large quantities of heteroatoms, while the amount theoretically required for selective heteroatom removal is only about $600 \mathrm{sct} / \mathrm{bbl}$. The problem is exacerbated as the number of rings in nitrogen and sulfur-containing molecules is increased. Hence, the saving in expensive hydrogen could be enormous, if tighter control of the denitrogenation process could be obtained.

This research program, funded by the Department of Energy (DOE) Office of Fossil Energy, Advanced Extraction and Process Technology (AEPT), provides accurate experimental thermochemical and thermophysical properties for "key" organic nitrogen-containing compounds present in heavier feedstocks, and applies the experimental information to thermodynamic analyses of key HDN reaction networks (e.g., quinoline/hydrogen, indole/hydrogen, acridine/hydrogen, etc.). Thermodynamic analyses, based on accurate information, can be used to set the boundaries (e.g., temperature range, pressure range, etc.) for efficient processing of materials, and to provide insights for the design of cost-effective methods of nitrogen removal.

This report outlines a new use of the thermodynamic property results. The measurements detailed in earlier Topical Reports from the Group are used to derive expressions for the relative rates of reaction of the divergent nitrogen-containing 
compounds present in heavier crudes. The results explain apparent contradictions existing in the literature on the kinetics of HDN of model compounds. In addition the power of the new methodology is shown in an explanation of the results of a HDN study on a straight-run gas oil. In that study, under some temperature and hydrogen pressure conditions, the amount of indoles increased by approximately 300 percent over their original concentration level. In addition, under certain temperature and hydrogen pressure conditions, anilines not present in the original gas oil sample were formed. This report explains those results in terms of the thermodynamics of the processes occurring in the straight-run gas oil. The report gives the process engineer a new insight into the interlocking of thermodynamics and kinetics in the complicated process of hydrodenitrogenation. Hopefully he/she can use the report as a stepping stone to the design of new effective catalysts and tighter hydrogen management of the process. 


\begin{abstract}
This report outlines a new use of thermodynamic property data. The Gibbs Energies of reaction obtained from thermodynamic property measurements are used to estimate, with some success, relative reactivities for aromatic organonitrogen compounds. Calculated relative rates of reaction reproduce literature values within one power of ten. The relative rates of reaction are shown to be directly proportional to the corcentration of hydrogenated species formed during hydrodenitrogenation (HDN). The production of completely saturated ring systems (overhydrogenation) in HDN reactions using conventional hydroprocessing is explained solely in terms of the thermodynamics in operation in the system. The results obtained show that the order of relative reactivity obtained is strongly dependent on the reaction temperature and hydroger pressure. This strong dependence can account for some apparent contradictions when kinetic studies reported in the literature are compared. The results for a study of the hydroprocessing of a straight-run gas oil are reproduced in this report. The formation of anilines and the increase in indole concentration above that in the original gas oil sample are explained via the thermodynamics operating in the system.
\end{abstract}

\title{
ACKNOW EDGEMENTS
}

The authors gratefully acknowledge the financial support of the Office of Frssil Energy of the U.S. Department of Energy. This research was funded within the Advanced Extraction and Process Technology (AEPT) program as part of the Cooperative Agreement DE-FC22-83FE60149.

The authors would like to take this opportunity to sadly note the passing of Dr. Paul R. Stapp. Paul, who died during the preparation of this report, provided numerous insights into methods of making the cold numbers of thermodynamic equilibria calculations into English prose capable of understanding by chemical engineers and even "pot-boiling organic chemists." His presence during the reviewing stages of reports will be sorely missed by the members of this Group.

The authors also acknowledge helpful discussions with William D. Peters (DOE Bartlesville Project Office), Ian R. Tasker, Dennis Ripley and Dexter Sutterfield (NIPER) and Marvin M. Johr.son (Phillips Petroleum Company) concerning the presentation of the results. All shortcomings remain the sole responsibility of the authors. 
Executive Summary

Abstract

Acknowledgements.

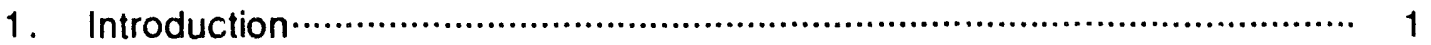



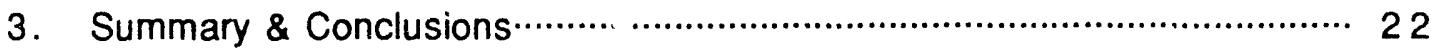

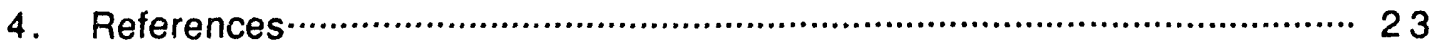

\section{LIST OF FIGURES}

FIGURE 1. Nitrogen-containing aromatic structures and their

hydrogenation products.....

FIGURE

2. Hydrogenolysis reactions during the HDN of aromatic nitrogen-containing compounds

FIGURE

3. Schematic representations of the $\sigma$ - and $\pi$ - type complexes on the catalyst surface.

FIGURE

4. Hydrogenolysis reactions during the HDN of quinoline and indole via partial and complete ring saturation pathways.....

FIGURE 4A. Examples of the effects of temperature and hydrogen pressure on the HDN of quinoline

FIGURE 4B. Examples of the effects of temperature and hydrogen pressure on the HDN of indole

FIGURE

5. Examples of the effects of temperature and hydrogen pressure on the HDN of quinoline under the reaction conditions used by Giola and Lee

\section{LIST OF TABLES}

TABLE 1. Equations to represent the hydrogenation equilibria considered in this report......

2. Values of the equilibrium constant $K^{\prime}$ determined using the equations listed in table 1 .....

TABLE

3. Relative rates of hydrogenolysis saturation determined using the equations listed in table 1 


\section{INTRODUCTION}

Within the petroleum industry, the use of catalytic hydroprocessing is increasing. Its application continues to grow as crudes become heavier and the range of speciality products increases. Over time its use can only continue to increase with the anticipated processing of oil shale, tar sands, and eventuaily the products of the liquefaction of coal. This report covers only a small (but increasingly important) area of catalytic hydroprocessing, namely hydrodenitrogenation (HDN). Other important areas within catalytic hydroprocessing include the hydrogenation of aromatics, hydrodesulfurization (HDS), and hydrodeoxygenation (HDO). This report is the product of research funded by the U. S. Department of Energy's (DOE) Office of Fossil Energy, Advanced Extraction \& Process Technology Program (AEPT). Within a portion of that research program, the thermochemical and thermophysical properties are determined for "key" organic nitrogen-containing compounds present in the spectrum of fossil-fuel materials. This report uses the results of thermodynamic property measurements to provide insights into the reaction networks and relative reactivities of nitrogen-containing components within the complicated process called hydrodenitrogenation.

As the specific gravity of crudes fed into refineries increases, the relative importance of catalytic hydrodenitrogenation (HDN) in the manufacture of petroleum products, especially gasoline, jet fuels and diesel, will increase.(1-5)§ In the petroleum industry, the long-term trend is toward heavier feedstocks containing larger percentages of nitrogen, oxygen, sulfur and aromatics. Nitrogen-containing compounds are particularly strong catalyst poisons. Therefore, a small increase in the weight percent nitrogen, as the refinery shifts to a new crude, can cause havoc within all areas of processing.

As crudes become heavier, the percentage of condensed-ring nitrogen heterocycles increases. In the heavier distillates most of the nitrogen is present in the form of condensed-ring heterocyclic compounds such as quinolines, phenanthridines, carbazoles and benzocarbazoles. $(1,5)$ As the nitrogen contents and aromaticities of the crudes increase, problems such as excessive catalyst coking also increase. $\left.{ }^{6}\right)$ The excessive coking is due in part to the strength of adsorption of the nitrogen-containing compounds on the catalyst surface. Nitrogen-containing compounds reaching the hydrocracker also cause serious problems. It has been noted that the ROT-65 function of the amount of nitrogen present.(7) $\mathrm{Nat}(7)$ found that the ROT-65 value

$\S$ References are listed in numerical order at the end of this report.

\# ROT-65 is defined as the Required Operating Temperature for conversion of $65 \%$ of the input to the hydrocracker to gasoline products. 
changed from $290^{\circ} \mathrm{C}$ to $390^{\circ} \mathrm{C}$ as the nitrogen level in the feed supplied was raised from $0 \mathrm{ppm}$ to $2000 \mathrm{ppm}$. In addition, some research ${ }^{(8)}$ points to nitrogen-containing components within processed fuels as major causes of subsequent instability during long-term storage or thermal stress.

Methods of removal of nitrogen-containing components from crudes are many and varied. They include various physical adsorption techniques and chemical reactions using specialty chemicals. However, although such techniques are highly suitable within the chemical laboratory, they are too expensive when transferred to the industria! environment. In particular, techniques involving separation require extensive control in operation and, for that reason, are usually precluded by economic considerations. Within the petroleum industry, the economic climate has meant that hydroprocessing is the only technique used at present for denitrogenation. For that reason only hydrodenitrogenation will be discussed in this report. Novel reactions such as:I

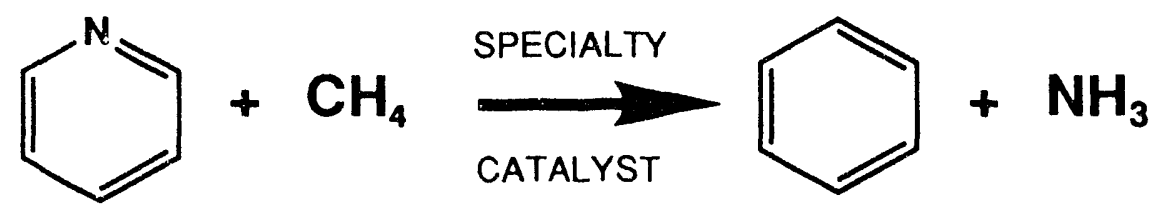

though thermodynamically possible, are not practical at present. The thermodynamics of the above (and other) reactions can be developed using the results of the thermodynamic property measurements reported by this group in various Office of Fossil Energy Topical Reports and journal articles. $†$

The problem of hydrodenitrogenation of feedstocks with resistant nitrogen components challenges the well-established methods used to process light feedstocks. Questions include:

- Why are some types of nitrogen-containing compounds more resistant to HDN than others?

- $\quad$ Can new catalysts be devised, which will improve the efficiency of removal of the resistant nitrogen compounds?

- Are the present reaction conditions the "best" for efficient removal of nitrogen from the heavier feedstocks?

1 The listed reaction is thermodynamically possible under all realizable conditions of temperature (and pressure) for all pyridinic compounds (quinolines, benzoquinolines etc.).

† A complete listing of the publications of the Bartlesville Thermodynamic Research Group is available upon request at the address given for the authors of this report. 
- Can a single reaction mechanism be applied to the HDN of all aromatic nitrogen-containing compounds?

- If (a) mechanism(s) can be determined, how will that help the design of a more effective catalyst?

Answers to these questions could open a pathway to a cleaner, more stable fuel slate without a large accompanying price increase.

Resistant nitrogen-containing compounds can be classified into three dominant types; anilines, pyrrolic compounds, and pyridinic compounds. This report considers pyrrole, pyridine, indole, quinoline, and carbazole as representative of the full range of aromatic ring nitrogen-containing compounds, except anilines, present in fossil fuel materials. It is believed that the conclusions drawn for these systems are equally applicable to substituted compounds (i.e., alkyl substituted systems) and larger ringsystems such as the benzoquinolines and benzocarbazoles.

\section{HYDRODENITROGENATION}

To develop improved HDN catalysts it is important to know the reaction pathways followed by heterocyclic aromatic nitrogen-containing compounds under industrially realizable conditions. Almost all kinetic studies reported in the literature were obtained with commercial hydroprocessing catalysts typified by sulfided $\mathrm{CoO}-\mathrm{MoO}_{3} / \gamma-\mathrm{Al}_{2} \mathrm{O}_{3}$ commonly used in hydrodesulfurization, sulfided $\mathrm{NiO}-\mathrm{MoO}_{3} / \gamma-\mathrm{Al}_{2} \mathrm{O}_{3}$ which has a higher hydrogenation activity than the former and is typically applied at present for HDN within the petroleum industry, and sulfided $\mathrm{NiO}-\mathrm{WO}_{3} / \gamma-\mathrm{Al}_{2} \mathrm{O}_{3}$. Studies on the kinetics of the HDN reaction for pyrroles, $(9,10)$ pyridines, $(11-15)$ indoles, $(16-22)$ quinolines, $(9,: 0,16,20,21,23-38)$ benzoquinolines, $(39-43)$ and carbazoles $(10,39,44-48)$ reported in the literature fail to agree on the reaction products or the reaction mechanism. Many of the studies were made at temperatures and pressures well removed from the present commercial processing conditions $\left(300^{\circ} \mathrm{C}\right.$ to $400^{\circ} \mathrm{C}$ and 75 to 150 atmospheres hydrogen pressure). The studies failed to produce a consensus on how the reacting molecules are absorbed onto the catalyst surface. In the majority of recent studies the formation of $\pi$ adsorbed species (through the aromatic system) are postulated whereas in the earlier work mechanisms with bonding through $\sigma$ nitrogen species were in vogue.

However, all the studies using sulfided catalysts do agree on one point. In HDN using sulfided catalysts, the aromatic nitrogen-containing ring requires saturation prior to the initial hydrogenolysis (ring-opening with hydrogen addition) step. Aromaticity imparts increased stability to cyclic structures. It requires considerably 
more energy to cleave an aromatic ring structure than it does to cleave a similar nonaromatic system. Although not exactly comparable, the $\mathrm{C}-\mathrm{N}$ single bond dissociation energy is listed(49) as $305 \mathrm{~kJ} \cdot \mathrm{mol}^{-1}$ compared to a value of $723 \mathrm{~kJ} \cdot \mathrm{mol}^{-1}$ for the $\mathrm{C}=\mathrm{N}$ bond dissociation energy. In the absence of a catalyst specially designed to nullify the effects of aromaticity, the activation energies for the ring-opening reactions will mirror the bond dissociation energies. The sulfided catalysts used in industry at present do not nullify the stability increase obtained by aromaticity.

Figure 1 shows the key aromatic nitrogen-containing entities considered in the remainder of this report. Also listed are the products of the degree of hydrogenation required to obtain saturation of the nitrogen-containing aromatic ring. Previous topical reports and journal articles(50-66) from this group have delineated the equilibria that are obtained between the aromatic and its saturated product for each of these key entities. For each of the aromatics there is supporting evidence in the literature $(4,5,16,19-22,25,26,30,31,36)$ for the attainment of equilibrium with the saturated-ring product under hydroprocessing conditions.

Figure 2 shows the hydrogenolysis reactions occurring when the saturated nitrogen-containing ring is opened via hydrogen addition. The rates of reactions can be expressed as:

$$
v=k \cdot\left[\mathrm{H}_{2}\right]^{m} \cdot[\mathrm{HP}]^{n},
$$

where $v$ is the velocity of each reaction, $k$ is the corresponding rate constant under constant temperature and pressure conditions, and $m$ and $n$ are the reaction orders with respect to hydrogen and HP (hydrogenation product in figures 1 and 2).

To simplify the ensuing discussion several assumptions will be made at this stage. 1) Since the reactions all occur under conditions where the hydrogen concentration (pressure) is large relative to that of the nitrogen-containing compound, the $\left[\mathrm{H}_{2}\right]^{m}$ term can be included within the $\mathbf{k}$ term. 2) It is assumed that the hydrogenolysis reactions are first order in the HPs listed in figures 1 and 2 . 3) More controversially, it is also assumed that $k$ has same value for all the nitrogen-containing compounds. This third assumption may appear at first sight to be untenable. However, if the reactions are occurring on the catalyst surface with the hydrogenated product adsorbed through a $\pi$-type complex, then, the assumption is not so untenable. Steric effects will be greatly decreased for $\pi$-type complexes as compared to adsorption via $N$ $\sigma$-type complexes (see figure 3). With the three assumptions listed above the rate of reaction expression is greatly simplified, and can be written as:

$$
\text { Velocity of reaction } v \propto[H P] .
$$


Aromatic reactant<smiles>c1cc[nH]c1</smiles>

Pyridine

Pyrrole<smiles>c1ccncc1</smiles>

Quinoline<smiles>c1ccc2ncccc2c1</smiles><smiles>c1ccc2[nH]ccc2c1</smiles>

Indole

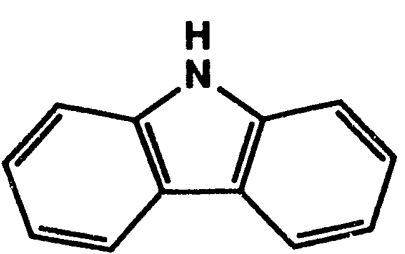

Hydrogenation product

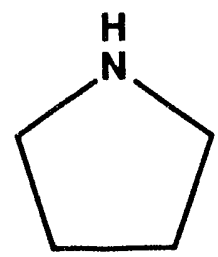<smiles>C1CCNCC1</smiles><smiles>c1ccc2c(c1)CCCN2</smiles><smiles>c1ccc2c(c1)CCN2</smiles><smiles>c1ccc2c(c1)NC1CCCCC21</smiles>

FIGURE 1. Nitrogen-containing aromatic ring compounds and their hydrogenation products. The listed hydrogenation products are the stable products formed as intermediates in the hydrodenitrogenation (HDN) reaction. 
Hydrogenation product

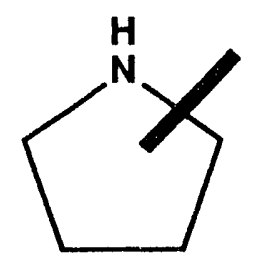<smiles>CC1(C)CCCNC1</smiles><smiles>C[C@@H]1CCc2ccccc2N1</smiles><smiles>[C]=C</smiles><smiles>C[C@@H]1CCc2ccccc2N1</smiles><smiles>C=C</smiles><smiles>CNc1ccccc1C1CCCC[C@H]1C</smiles><smiles>C=C</smiles>

Hydrogenolysis product

$\mathrm{CH}_{3} \mathrm{CH}_{2} \mathrm{CH}_{2} \mathrm{CH}_{2} \mathrm{NH}_{2}$

$\mathrm{CH}_{3} \mathrm{CH}_{2} \mathrm{CH}_{2} \mathrm{CH}_{2} \mathrm{CH}_{2} \mathrm{NH}_{2}$<smiles>CCCc1ccccc1N</smiles><smiles>CCc1ccccc1N</smiles><smiles>Nc1ccccc1C1CCCCC1</smiles>

FIGURE 2. Hydrogenolysis reactions during the HDN of aromatic nitrogen-containing compounds. 


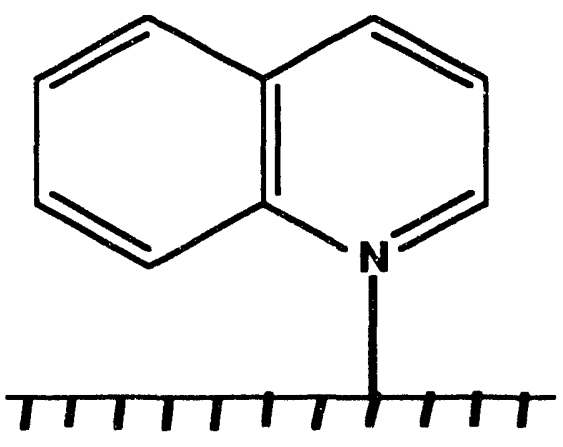

$\sigma$-complex



ח-complex

FIGURE 3. Schematic representations of $\sigma$ - and $\pi$ - type complexes on the catalyst surface.

The use of equation 2 in a comparison of the relative rates of hydrogenolysis to the products listed in figure 2 requires a knowledge of the concentration of HP in each case. If HP is formed under thermodynamic equilibrium conditions, its concentration can be determined directly from the Gibbs energy of the reaction. Table 1 lists equations, which represent the equilibrium between the aromatic nitrogen-containing compound and its hydrogenated product, for each of the entities considered here. In table $1, K^{\prime}$ equals the ratio of the concentrations of the hydrogenated product to the aromatic (e.g., for pyrrole $K^{\prime}=$ [pyrrolidine]/[pyrrole]), $T$ is the temperature in Kelvin $\left(T / K=V^{\circ} \mathrm{C}+273.15\right)$, and $p$ is the pressure in atmospheres (1 atmosphere $=101.325 \mathrm{kPa}=14.696 \mathrm{psia})$. The standard pressure (denoted $\mathrm{p}^{\circ}$ ), used in the derivation of the equations representing the equilibria, is 1 atmosphere.

Table 2 lists the values of the equilibrium constant $K^{\prime}$ obtained using the equations of table 1 at various representative temperatures and hydrogen pressures. In table 3 the equilibrium constants are normalized using the values obtained for carbazole as the baseline. The values listed in table 3 can be considered relative rates of hydrogenolysis. They are not always the relative rates of hydrodenitrogenation (HDN). For pyrrole and pyridine, since primary amines are the product of the hydrogenolysis reaction, then, the hydrogenolysis rates are also the rates of HDN (in those cases the subsequent ammonia formation steps are several factors of 10 faster than the 
TABLE 1. Equations to represent the hydrogenation equilibria considered in this report.

Pyrrole/Pyrrolidine

$$
\ln K^{\prime}=14400 / T-29.47+2 \cdot\left[\ln \left(P_{H_{2}} / P^{\circ}\right)\right]
$$

Pyridine/Piperidine

$$
\ln K^{\prime}=23470 / T-46.06+3 \cdot\left[\ln \left(P_{H_{2}} / P^{\circ}\right)\right]
$$

Quinoline/1,2,3,4-Tetrahydroquinoline

$$
\ln K^{\prime}=14350 / T-28.64+2 \cdot\left[\ln \left(P_{H_{2}} / P^{\circ}\right)\right]
$$

Indole/Indoline

$$
\text { In } K^{\prime}=4940 / T-13.42+\left[\ln \left(P_{H_{2}} / P^{\circ}\right)\right]
$$

Carbazole/1,2,3,4,4a,9a-Hexahydrocarbazole

$$
\ln K^{\prime}=16490 / T-42.61+3 \cdot\left[\ln \left(P_{H_{2}} / P^{\circ}\right)\right]
$$

\section{Quinoline/trans-Decahydroquinoline}

$$
\ln K^{\prime}=38570 / T-76.22+5 \cdot\left[\ln \left(P_{H_{2}} / P^{\circ}\right)\right]
$$

Indole/cis-Perhydroindole

$$
\ln K^{\prime}=25770 / T-52.15+4 \cdot\left[\ln \left(P_{H_{2}} / P^{\circ}\right)\right]
$$


TABLE 2. Values of the equilibrium constant $K^{\prime}$ determined using the equations listed in Table 1.

\section{Pyrrole/Pyrrolidine}

Hydrogen

$\begin{array}{cc}\text { atm. } & 100^{\circ} \mathbf{C} \\ 10 & 9.21 E+05 \\ 25 & 5.76 E+06 \\ 50 & 2.30 E+07 \\ 75 & 5.18 E+07 \\ 100 & 9.21 E+07 \\ 125 & 1.44 E+08 \\ 150 & 2.07 E+08 \\ 175 & 2.82 E+08 \\ 200 & 3.68 E+08\end{array}$

$\begin{array}{cc}200^{\circ} \mathbf{C} & 300^{\circ} \mathbf{C} \\ 2.53 E+02 & 1.26 E+00 \\ 1.58 E+03 & 7.86 E+00 \\ 6.33 E+03 & 3.14 E+01 \\ 1.43 E+04 & 7.08 E+01 \\ 2.53 E+04 & 1.26 E+02 \\ 3.96 E+04 & 1.97 E+02 \\ 5.70 E+04 & 2.83 E+02 \\ 7.76 E+04 & 3.85 E+02 \\ 1.01 E+05 & 5.03 E+02\end{array}$

$400^{\circ} \mathrm{C}$

$3.02 \mathrm{E}-02$

$1.89 \mathrm{E}-01$

7.55E-01

$1.70 E+00$

$3.02 E+00$

$4.72 \mathrm{E}+00$

$6.80 \mathrm{E}+00$

$9.25 \mathrm{E}+00$

$1.21 \mathrm{E}+01$

\section{Pyridine/Piperidine}

Hydrogen

atm.

10

25

50

75

100

125

150

175

200 $100^{\circ} \mathrm{C}$

$2.12 E+10$

$3.32 E+11$

2. $65 \mathrm{E}+12$

$8.95 E+12$

$2.12 E+13$

$4.14 E+13$

$7.16 E+13$

$1.14 E+14$

$1.70 E+14$ $200^{\circ} \mathrm{C}$

$3.54 \mathrm{E}+04$

$5.53 \mathrm{E}+05$

$4.42 E+06$

$1.49 \mathrm{E}+07$

$3.54 \mathrm{E}+07$

$6.91 E+07$

$1.19 \mathrm{E}+08$

$1.90 \mathrm{E}+08$

$2.83 E+08$ $300^{\circ} \mathrm{C}$

$6.13 E+00$

$9.57 E+01$

$7.66 \mathrm{E}+02$

$2.59 E+03$

$6.13 E+03$

$1.20 E+04$

2. $07 E+04$

$3.28 E+04$

$4.90 E+04$ $400^{\circ} \mathrm{C}$

1.39E-02

2.18E-01

$1.74 \mathrm{E}+00$

$5.87 E+00$

$1.39 E+01$

2.72E+01

4.70E+01

$7.46 \mathrm{E}+01$

$1.11 \mathrm{E}+02$

\section{Quinoline/1,2,3,4-Tetrahydroquinoline}

Hydrogen

$\begin{array}{cc}\text { atm. } & 100^{\circ} \mathrm{C} \\ 10 & 3.02 E+06 \\ 25 & 1.89 E+07 \\ 50 & 7.54 E+07 \\ 75 & 1.70 E+08 \\ 100 & 3.02 E+08 \\ 125 & 4.71 E+08 \\ 150 & 6.79 E+08 \\ 175 & 9.24 E+08 \\ 200 & 1.21 E+09\end{array}$

$200^{\circ} \mathrm{C}$
$7.99 E+02$
$5.00 E+03$
$2.00 E+04$
$4.50 E+04$
$7.99 E+04$
$1.25 E+05$
$1.80 E+05$
$2.45 E+05$
$3.20 E+05$

$300^{\circ} \mathrm{C}$

3.75E+00

2.35E+01

$9.39 E+01$

2.11E+02

3.75E+02

$5.87 E+02$

8.45E+02

$1.15 E+03$

$1.50 E+03$ $400^{\circ} \mathrm{C}$

8.67E-02

$5.42 E-01$

$2.17 E+00$

$4.88 \mathrm{E}+00$

$8.67 E+00$

1.36E+01

$1.95 E+01$

2.66E+01

$3.47 E+01$ 
TABLE 2. Continued

Indole/Indoline

\begin{tabular}{|c|c|c|c|c|}
\hline $\begin{array}{c}\text { Hydrogen } \\
\text { atm. }\end{array}$ & $100^{\circ} \mathrm{C}$ & $200^{\circ} \mathrm{C}$ & $300^{\circ} \mathrm{C}$ & $400^{\circ} \mathrm{C}$ \\
\hline 10 & $8.39 E+00$ & $5.10 E-01$ & $8.24 E-02$ & $2.29 E-02$ \\
\hline 25 & $2.10 E+01$ & $1.27 E+00$ & $2.06 E-01$ & $5.72 \mathrm{E}-02$ \\
\hline 50 & $4.19 E+01$ & $2.55 E+00$ & $4.12 E-01$ & $1.14 \mathrm{E}-01$ \\
\hline 75 & $6.29 E+01$ & $3.82 E+00$ & $6.18 E-01$ & $1.72 \mathrm{E}-01$ \\
\hline 100 & $8.39 E+01$ & $5.10 E+00$ & $8.24 E-01$ & $2.29 E-01$ \\
\hline 125 & $1.05 E+02$ & $6.37 \bar{E}+00$ & $1.03 E+00$ & $2.86 E-01$ \\
\hline 150 & $1.26 E+02$ & $7.65 E+00$ & $1.24 E+00$ & $3.43 E-01$ \\
\hline 175 & $1.47 E+02$ & $8.92 E+00$ & $1.44 E+00$ & $4.01 E-01$ \\
\hline 200 & $1.68 E+02$ & $1.02 E+01$ & $1.65 E+00$ & $4.58 E-01$ \\
\hline
\end{tabular}

Carbazole/cis-1,2,3,4,4a,9a-Hexahydrocarbazole

Hydrogen atm.

$10 \quad 4.95 E+03$

$25 \quad 7.73 E+04$

$50 \quad 6.19 \mathrm{E}+05$

$75 \quad 2.09 E+06$

100

125

150

175

200
4.95E+06

$9.67 E+06$

1.67E+07

$2.65 E+07$

$3.96 E+07$ $200^{\circ} \mathrm{C} \quad 300^{\circ} \mathrm{C} \quad 400^{\circ} \mathrm{C}$

5.34E-01 1.17E-03 1.59E-05

8.34E+00 1.83E-02 2.48E-04

$6.67 E+01 \quad 1.46 E-01 \quad 1.98 E-03$

$2.25 E+02 \quad 4.94 E-01 \quad 6.69 E-03$

$5.34 E+02 \quad 1.17 E+00 \quad 1.59 E-02$

$1.04 E+03 \quad 2.29 E+00 \quad 3.10 E-02$

$1.80 E+03$

$3.95 E+00$

5.35E-02

$2.86 E+03$

$6.28 E+00$

8.50E-02

4.27E+03

1.27E-01 
TABLE 3. Relative rates of hydrogenolysis. Carbazole is taken as the baseline in the calculation of the relative rates. The marked area denotes the range of present HDN reaction conditions used in industry.

\section{Pyrrole/Pyrrolidine}

Hydrogen

$\begin{array}{cc}\text { atm. } & 100^{\circ} \mathrm{C} \\ 10 & 186 \\ 25 & 74 \\ 50 & 37 \\ 75 & 25 \\ 100 & 19 \\ 125 & 15 \\ 150 & 12 \\ 175 & 11 \\ 200 & 9\end{array}$

\begin{tabular}{ccc|}
$200^{\circ} \mathrm{C}$ & $300^{\circ} \mathrm{C}$ & $400^{\circ} \mathrm{C}$ \\
475 & 1074 & 1905 \\
190 & 429 & 762 \\
95 & 215 & 381 \\
63 & 143 & 254 \\
47 & 107 & 190 \\
38 & 86 & 152 \\
32 & 72 & 127 \\
27 & 61 & 109 \\
24 & 54 & 95
\end{tabular}

\section{Pyridine/Piperidine}

Hydrogen

atm.
10
25
50
75
100
125
150
175
200

$100^{\circ} \mathrm{C}$

$4.3 E+6$

$4.3 E+6$

$4.3 E+6$

$4.3 E+6$

4. $3 E+6$

4. $3 E+6$

$4.3 E+6$

$4.3 E+6$

$4.3 E+6$ $200^{\circ} \mathrm{C}$

$6.6 \mathrm{E}+4$

$6.6 E+4$

$6.6 \mathrm{E}+4$

$6.6 E+4$

$6.6 \mathrm{E}+4$

$6.6 \mathrm{E}+4$

$6.6 E+4$

$6.6 E+4$

$6.6 E+4$

\begin{tabular}{|cc|}
$300^{\circ} \mathrm{C}$ & $400^{\circ} \mathrm{C}$ \\
5230 & 878 \\
5230 & 878 \\
5230 & 878 \\
\hline 5230 & 878 \\
5230 & 878 \\
5230 & 878 \\
5230 & 878 \\
\hline 5230 & 878 \\
5230 & 878 \\
\hline
\end{tabular}

\section{Quinoline/1,2,3,4-Tetrahydroquinoline}

Hydrogen atm.

10

25

50

75

100

125

150

175

200 $100^{\circ} \mathrm{C}$

610

244

122

81

61

49

41

35

30

$200^{\circ} \mathrm{C}$
1499
599
300
200
150
120
100
86
75

\begin{tabular}{|cc|}
\hline $300^{\circ} \mathrm{C}$ & $400^{\circ} \mathrm{C}$ \\
3204 & 5467 \\
1282 & 2187 \\
641 & 1093 \\
\hline 427 & 729 \\
320 & 547 \\
256 & 437 \\
214 & 364 \\
\hline 183 & 312 \\
160 & 273 \\
\hline
\end{tabular}


TABLE 3. Continued

Indole/Indoline

Hydrogen

$\begin{array}{ccccc}\text { atm. } & 100^{\circ} \mathbf{C} & 200^{\circ} \mathbf{C} & 300^{\circ} \mathbf{C} & 400^{\circ} \mathbf{C} \\ 10 & 1.7 E-3 & 0.956 & 70 & 1443 \\ 25 & 2.7 E-4 & 0.153 & 11 & 231 \\ 50 & 6.8 E-5 & 0.038 & 3 & 58 \\ 75 & 3.0 E-5 & 0.017 & 1 & 26 \\ 100 & 1.7 E-5 & 0.01 & 1 & 14 \\ 125 & 1.1 E-5 & 0.006 & 0.45 & 9 \\ 150 & 7.5 E-6 & 0.004 & 0.31 & 6 \\ 175 & 5.5 E-6 & 0.003 & 0.23 & 5 \\ 200 & 4.2 E-5 & 0.002 & 0.18 & 4\end{array}$

Carbazole/cis-1,2,3,4,4a,9a-Hexahydrocarbazole

Hydrogen

$\begin{array}{ccccc}\text { atm. } & 100^{\circ} \mathbf{C} & 200^{\circ} \mathbf{C} & 300^{\circ} \mathbf{C} & 400^{\circ} \mathbf{C} \\ 10 & 1 & 1 & 1 & 1 \\ 25 & 1 & 1 & 1 & 1 \\ 50 & 1 & 1 & 1 & 1 \\ 75 & 1 & 1 & 1 & 1 \\ 100 & 1 & 1 & 1 & 1 \\ 125 & 1 & 1 & 1 & 1 \\ 150 & 1 & 1 & 1 & 1 \\ 175 & 1 & 1 & 1 & 1 \\ 200 & 1 & 1 & 1 & 1\end{array}$


hydrogenolysis(2,5,11,15)). For quinoline, indole, and carbazole, the products of the hydrogenolysis reactions considered here are anilines, which are also difficult to hydrodenitrogenate $(5,10,20,30)$ so they are not the relative rates of HDN.

The results listed in table 3 are an excellent example of the sensitive interaction betweon hydrogen pressure and temperature in the hydrogenolysis reactions. The relative rates of reaction vary over TWELVE powers of ten. No one aromatic nitrogencontaining compound is the least reactive over the temperature and pressure ranges chosen. Indeed there is substantial crossover in relative reactivity as the temperature and pressure are varied. For example, at $100^{\circ} \mathrm{C}$ and 200 atmospheres hydrogen pressure the order of increasing reactivity is:

$$
\text { indole } \ll<\text { carbazole } \approx \text { pyrrole } \approx \text { quinoline } \ll \text { pyridine }
$$

but at $400^{\circ} \mathrm{C}$ and 10 atmospheres hydrogen pressure the order of increasing reactivity has become:

$$
\text { carbazole } \ll \text { pyridine }<\text { indole } \approx \text { pyrrole } \ll \text { quinoline. }
$$

Even within the range of "conventional" HDN reactions in operation in industry (75 to 150 atmospheres hydrogen pressure in the temperature range $300^{\circ} \mathrm{C}$ to $400^{\circ} \mathrm{C}$ ) the relative reactivities vary. For example, the relative reactivity of pyridine decreases by a factor of 4 (5230 to 878) as trie operating conditions change from $300^{\circ} \mathrm{C}$ and 75 atmospheres hydrogen pressure to $400^{\circ} \mathrm{C}$ and 150 atmospheres hydrogen pressure.

The results listed in table 3 are only significant if they can be replicated in studies of relative reactivities etc., performed in the laboratory or in pilot plants. The obtaining of collaboratory evidence for the results reported here from the available literature is difficult. As stated by Girgis and Gates $(5)$ in their 1991 review of hydroprocessing. "Comparisons of reactivities of basic and non-basic organonitrogen compounds are few." They report only two studies. $(10,16)$

Stern $(10)$ reported rates of disappearance of pyrrole, indole, and carbazole in a $\mathrm{HDN}$ study using a $\mathrm{NiO}-\mathrm{MOO}_{3} / \gamma-\mathrm{Al}_{2} \mathrm{O}_{3}$ catalyst at $350^{\circ} \mathrm{C}$ and under 68 atmospheres pressure of hydrogen. The relative rates reported by Stern were $3.30: 1.16: 0.12$ for pyrrole:indole:carbazole, respectively, i.e., a ratio of $27.5: 10: 1$. Interpolation of the results reported in table 3 for the conditions used by Stern gives a ratio of $215: 8: 1$. There is excellent agreement in the carbazole/indole ratios, but a factor of 10 difference exists in the case of pyrrole. The difference could be explained, if the rate constant, $k$, for pyrrole hydrogenolysis is a factor of 10 less than those of indole or carbazole. However, there is no obvious reason for that to be true, whereas chemical intuition 
(e.g., steric effects) points to the reverse; the rate constant for pyrrole being larger than indole or carbazole.

The second study of comparative reactivities noted by Girgis and Gates $(5)$ was reported by Bhinde et al.(16) Conditions under which the comparisons were made were $350^{\circ} \mathrm{C}, 34$ atmospheres hydrogen pressure with $\mathrm{CoO}-\mathrm{MoO}_{3} / \gamma-\mathrm{Al}_{2} \mathrm{O}_{3}$, $\mathrm{NiO}-\mathrm{MOO}_{3} / \gamma-\mathrm{Al}_{2} \mathrm{O}_{3}$, and $\mathrm{NiO}-\mathrm{WO}_{3} / \gamma-\mathrm{Al}_{2} \mathrm{O}_{3}$ catalysts. Bhinde et al. in their study found that nitrogen removal rates were similar for quinoline and indole. They reported first order rate constants of $4.19 \cdot 10^{-6}\left(\mathrm{l} / \mathrm{g}\right.$. catalyst.s) and $3.81 \cdot 10^{-6}(\mathrm{l} / \mathrm{g}$. catalyst.s) for indole and quinoline, respectively. (The initial concentration of indole was 10 percent less than that for quinoline.) Interpolation of the results reported in table 3 for the conditions used by Bhinde et al. gives a ratio of $16: 1$ for the quinoline to indote relative rates ratio, in apparent disagreement with Bhinde et al.(16)

However, a closer comparison of the results obtained by Bhinde et al.(16) shows that in the study of the nitrogen removal rates the major products of the reactions were propylcyclohexane and ethylcyclohexane for quinoline and indole, respectively. Therefore, the methodology used above to compare the relative rates requires modification to allow for cemplete ring saturation prior to the hydrogenolysis step. Figure 4 shows the possible reaction schemes for the system as studied by Bhinde et al.(16)

Table 4 lists the values of the equilibrium constant $K^{\prime}$ obtained using the equations of table 1 for the "new" reactions to be considered in the full picture, i.e., quinoline/trans-decahydroquinoline and indole/cis-perhydroindole. Table 5 lists the revised relative rates for the hydrogenolysis reactions given in figure 4 . Interpolation of the quinoline/trans-decahydroquinoline results for the conditions used by Bhinde et al. (16) gives a relative rate of hydrogenolysis of $7.5 \mathrm{E}+04$ at $350^{\circ} \mathrm{C}, 34$ atmospheres hydrogen pressure and a similar interpolation of the indole/cis-perhydroindole results gives a relative rate of hydrogenolysis of $1.5 \mathrm{E}+04$. Hence, a ratio of $5: 1$ for the quinoline to indole relative rates is obtained using this broader picture. Although this is not perfect agreement with the values given by Bhinde et al., ${ }^{(16)}$ the agreement is good considering the original simplifications used in deriving equation 2 (see page 4).

Table 6 lists ratios of the hydrogenolysis reaction rates for the formation of the cyclohexylamine versus the aniline analogue (see figures $4,4 A$, and $4 B$ ). Note that at low temperature $<200^{\circ} \mathrm{C}$ the formation of the cyclohexylamine is strongly favored for both quinoline and indole. However, at $400^{\circ} \mathrm{C}$ the aniline formation pathway becomes increasingly probable, especially as the hydrogen pressure is decreased. This result sheds some light on the apparent contradiction in the literature between the results 


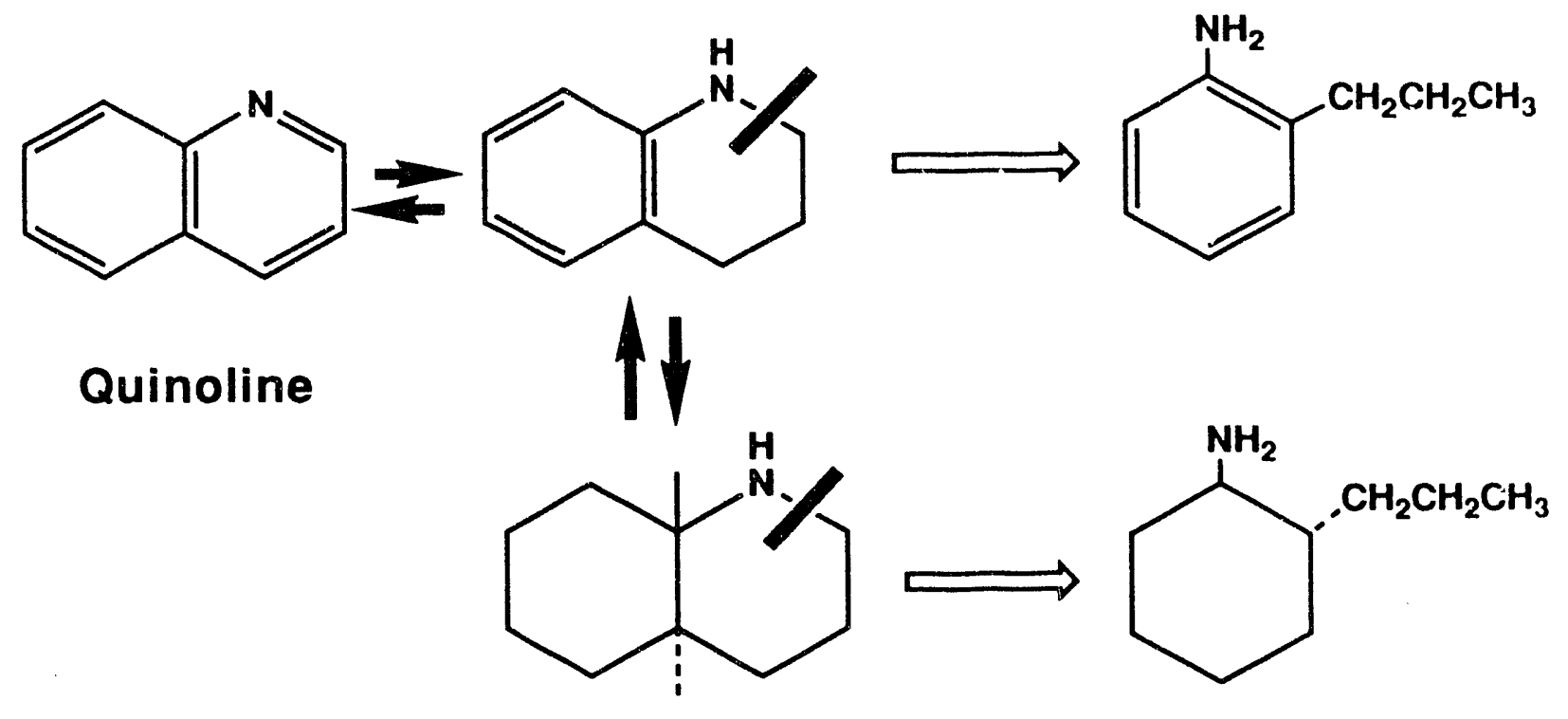<smiles>Cc1cc2ccccc2[nH]1</smiles><smiles>CCc1ccccc1N</smiles>

FIGURE 4. Hydrogenolysis reactions during the HDN of quinoline and indole via partial and complete ring saturation pathways. 
Favored by high temperature and low hiydrogen pressure e.g., at $400{ }^{\circ} \mathrm{C}$ and 25 atmospheres hydrogen pressure the relative rate ratio (Table 6 inverse of 0.012 ) favors this product by a factor of 83; however at $300^{\circ} \mathrm{C}$ and the same hydrogen pressure the factor is less than unity $(0.0003)$ i.e., the cyclohexylamine product is favored by a factor of 3 thousand.

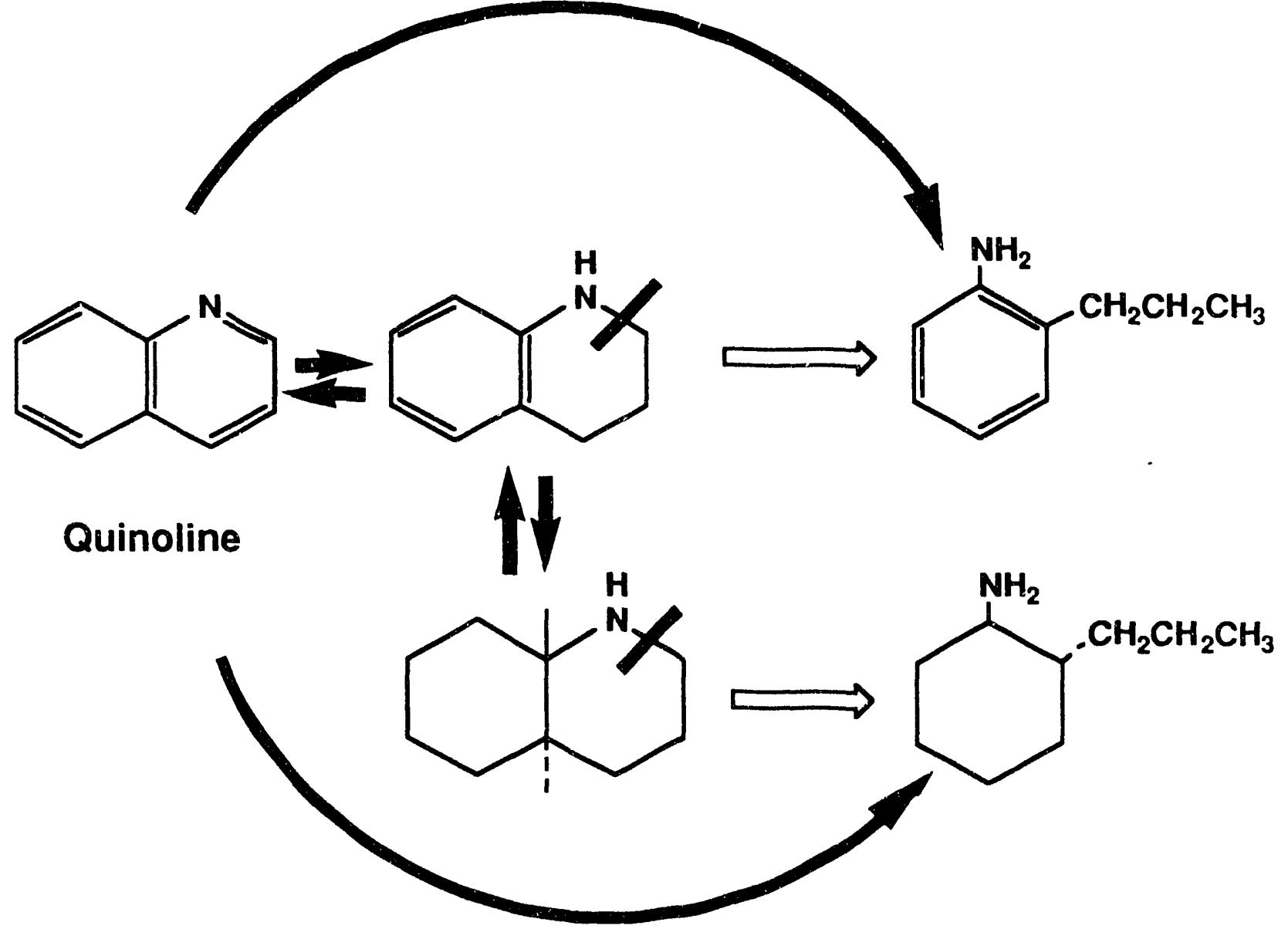

Favored by low temperature and high hydrogen pressure e.g., at $400^{\circ} \mathrm{C}$ and 75 atmospheres hydrogen pressure the relative rate ratio (Table 6) favors this product by a factor of 9 ; however at $300^{\circ} \mathrm{C}$ and the same hydrogen pressure the factor is 2.3 million!

FIGURE 4A. Examples of the effects of temperature and hydrogen pressure on the HDN of quinoline. 
Favored by high temperature and low hydrogen pressure e.g., at $400{ }^{\circ} \mathrm{C}$ and 10 atmospheres hydrogen pressure the relative rate ratio (Table 6 inverse of 0.18 ) favors this product by a factor of 5.6; however at $300^{\circ} \mathrm{C}$ and the same hydrogen pressure the factor is less than unity $(0.0001)$ i.e., the cyclohexylamine product is favored by a factor of over 8600 .

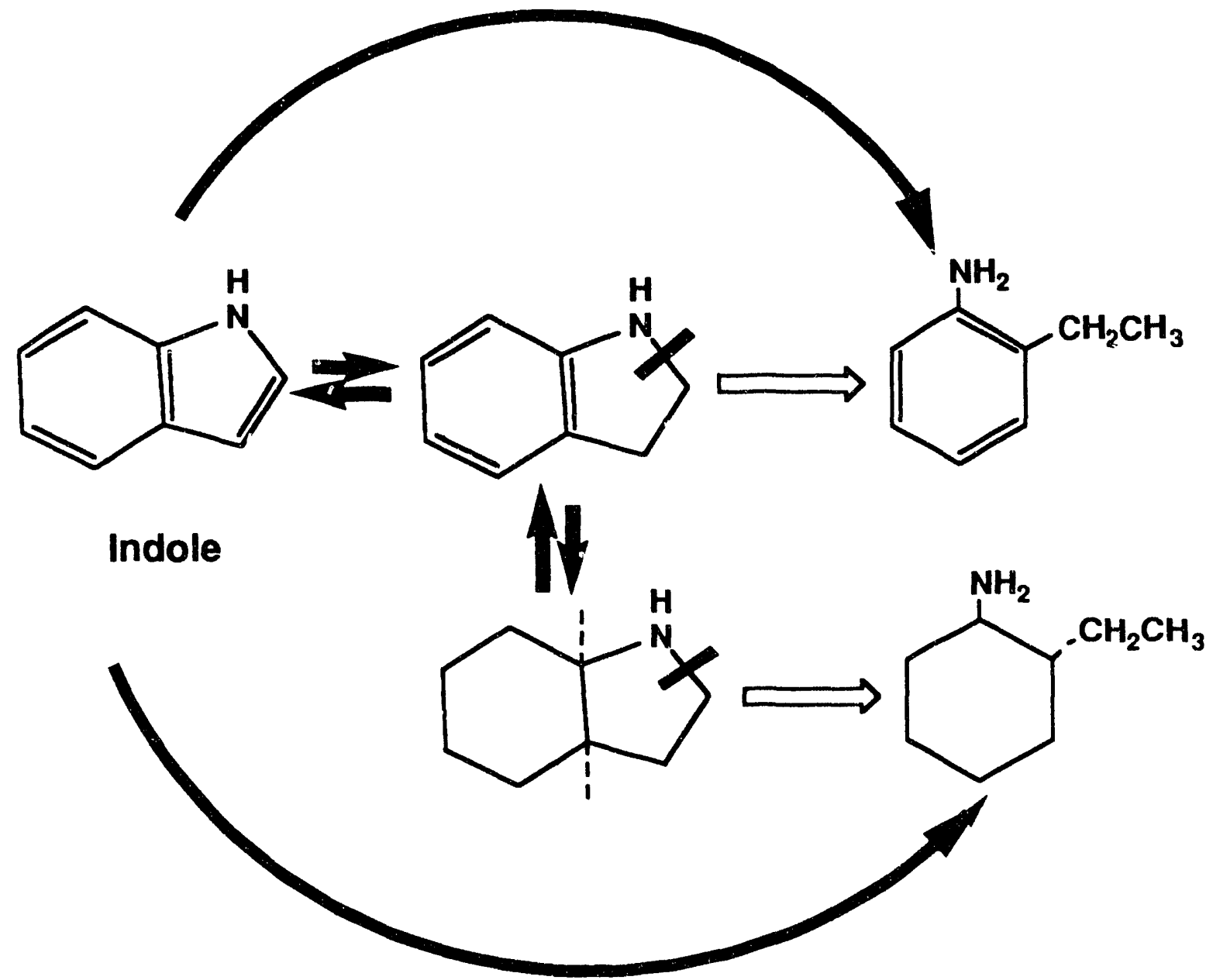

Favored by low temperature and high hydrogen pressure e.g., at $400{ }^{\circ} \mathrm{C}$ and 50 atmospheres hydrogen pressure the relative rate ratio (Table 6) favors this product by a factor of 2700 ; however at $300^{\circ} \mathrm{C}$ and the same hydrogen pressure the factor is 130 million!

FIGURE 4B. Examples of the effects of temperature and hydrogen pressure on the HDN of indole. 
TABLE 4. Values of the equilibrium constant $K^{\prime}$ for complete ring saturation determined using the equations listed in Table 1.

\section{Quinoline/trans-Decahydroquinoline}

Hydrogen

$\begin{array}{ccccc}\text { atm. } & 100^{\circ} \mathbf{C} & 200^{\circ} \mathbf{C} & 300^{\circ} \mathbf{C} & 400^{\circ} \mathbf{C} \\ 10 & 6.43 E+16 & 2.06 E+07 & 1.36 E+01 & 6.15 E-04 \\ 25 & 6.28 E+18 & 2.01 E+09 & 1.33 E+03 & 6.01 E-02 \\ 50 & 2.01 E+20 & 6.44 E+10 & 4.24 E+04 & 1.92 E+00 \\ 75 & 1.53 E+21 & 4.89 E+11 & 3.22 E+05 & 1.46 E+01 \\ 100 & 6.43 E+21 & 2.06 E+12 & 1.36 E+06 & 6.15 E+01 \\ 125 & 1.96 E+22 & 6.28 E+12 & 4.15 E+06 & 1.88 E+02 \\ 150 & 4.89 E+22 & 1.56 E+13 & 1.03 E+07 & 4.67 E+02 \\ 175 & 1.06 E+23 & 3.38 E+13 & 2.23 E+07 & 1.01 E+03 \\ 200 & 2.06 E+23 & 6.59 E+13 & 4.35 E+07 & 1.97 E+03\end{array}$

Indole/cis-Perhydroindole

Hydrogen

$\begin{array}{ccccc}\text { atm. } & 100^{\circ} \mathrm{C} & 200^{\circ} \mathrm{C} & 300^{\circ} \mathrm{C} & 400^{\circ} \mathrm{C} \\ 10 & 2.27 \mathrm{E}+11 & 1.03 \mathrm{E}+05 & 7.65 \mathrm{E}+00 & 9.58 \mathrm{E}-03 \\ 25 & 8.87 \mathrm{E}+12 & 4.02 \mathrm{E}+06 & 2.99 \mathrm{E}+02 & 3.74 \mathrm{E}-01 \\ 50 & 1.42 \mathrm{E}+14 & 6.44 \mathrm{E}+07 & 4.78 \mathrm{E}+03 & 5.99 \mathrm{E}+00 \\ 75 & 7.19 \mathrm{E}+14 & 3.26 \mathrm{E}+08 & 2.42 \mathrm{E}+04 & 3.03 \mathrm{E}+01 \\ 100 & 2.27 \mathrm{E}+15 & 1.03 \mathrm{E}+09 & 7.65 \mathrm{E}+04 & 9.58 \mathrm{E}+01 \\ 125 & 5.55 \mathrm{E}+15 & 2.51 \mathrm{E}+09 & 1.87 \mathrm{E}+05 & 2.34 \mathrm{E}+02 \\ 150 & 1.15 \mathrm{E}+16 & 5.21 \mathrm{E}+09 & 3.87 \mathrm{E}+05 & 4.85 \mathrm{E}+02 \\ 175 & 2.13 \mathrm{E}+16 & 9.66 \mathrm{E}+09 & 7.17 \mathrm{E}+05 & 8.98 \mathrm{E}+02 \\ 200 & 3.63 \mathrm{E}+16 & 1.65 \mathrm{E}+10 & 1.22 \mathrm{E}+06 & 1.53 \mathrm{E}+03\end{array}$


TABLE 5. Revised relative rates of hydrogenolysis. In these calculations boin the partial saturation and the full saturation pathways are included.

\section{Quinoline/1,2,3,4-Tetrahydroquinoline}

\section{Hydrogen}

$\begin{array}{ccccc}\text { atm. } & 100^{\circ} \mathrm{C} & 200^{\circ} \mathrm{C} & 300^{\circ} \mathrm{C} & 400^{\circ} \mathrm{C} \\ 10 & 2.9 \mathrm{E}-08 & 0.058 & 694 & 5429 \\ 25 & 7.3 \mathrm{E}-10 & 0.001 & 22 & 1969 \\ 50 & 4.6 \mathrm{E}-11 & 9.3 \mathrm{E}-05 & 1.4 & 580 \\ 75 & 9.0 \mathrm{E}-12 & 1.8 \mathrm{E}-05 & 0.280 & 183 \\ 100 & 2.9 \mathrm{E}-12 & 5.8 \mathrm{E}-06 & 0.089 & 68 \\ 125 & 1.2 \mathrm{E}-12 & 2.4 \mathrm{E}-06 & 0.036 & 29 \\ 150 & 5.6 \mathrm{E}-13 & 1.1 \mathrm{E}-06 & 0.017 & 15 \\ 175 & 3.0 \mathrm{E}-13 & 6.2 \mathrm{E}-07 & 0.009 & 8 \\ 200 & 1.8 \mathrm{E}-13 & 3.6 \mathrm{E}-07 & 0.006 & 5\end{array}$

\section{Quinoline/trans-Decahydroquinoline}

Hydrogen

$\begin{array}{cc}\text { atm. } & 100^{\circ} \mathrm{C} \\ 10 & 1.3 E+13 \\ 25 & 8.1 E+13 \\ 50 & 3.3 E+14 \\ 75 & 7.3 E+14 \\ 100 & 1.3 E+15 \\ 125 & 2.0 E+15 \\ 150 & 2.9 E+15 \\ 175 & 4.0 E+15 \\ 200 & 5.2 E+15\end{array}$

$200^{\circ} \mathrm{C}$

$3.9 \mathrm{E}+7$

$2.4 E+8$

$9.6 \mathrm{E}+8$

$2.2 E+9$

$3.9 E+9$

$6.0 E+9$

8.7E+9

$1.2 E+10$

$1.5 E+10$ $300^{\circ} \mathrm{C}$

$9.1 \mathrm{E}+3$

7.1E+4

$2.9 E+5$

$6.5 E+5$

1. $2 E+6$

1. $8 E+6$

2. $6 E+6$

3. $6 E+6$

4. $6 E+6$ $400^{\circ} \mathrm{C}$

0.27

24

456

1635

3399

5651

8375

$1.2 E+4$

$1.5 E+4$ 
TABLE 5. Continued.

Indole/Indoline

Hydrogen

$\begin{array}{ccccc}\text { atm. } & 100^{\circ} \mathrm{C} & 200^{\circ} \mathrm{C} & 300^{\circ} \mathrm{C} & 400^{\circ} \mathrm{C} \\ 10 & 6.3 \mathrm{E}-14 & 4.7 \mathrm{E}-06 & 0.75 & 1000 \\ 25 & 6.4 \mathrm{E}-16 & 4.8 \mathrm{E}-08 & 0.008 & 31 \\ 50 & 2.0 \mathrm{E}-17 & 1.5 \mathrm{E}-09 & 2.4 \mathrm{E}-04 & 1.1 \\ 75 & 2.6 \mathrm{E}-18 & 2.0 \mathrm{E}-10 & 3.2 \mathrm{E}-05 & 0.14 \\ 100 & 6.3 \mathrm{E}-19 & 4.7 \mathrm{E}-11 & 7.6 \mathrm{E}-06 & 0.034 \\ 125 & 2.1 \mathrm{E}-19 & 1.6 \mathrm{E}-11 & 2.5 \mathrm{E}-06 & 0.011 \\ 150 & 8.2 \mathrm{E}-20 & 6.2 \mathrm{E}-12 & 1.0 \mathrm{E}-06 & 0.0045 \\ 175 & 3.8 \mathrm{E}-20 & 2.9 \mathrm{E}-12 & 4.6 \mathrm{E}-07 & 0.0021 \\ 200 & 2.0 \mathrm{E}-20 & 1.5 \mathrm{E}-12 & 2.4 \mathrm{E}-07 & 0.0011\end{array}$

indole/cis-Perhydroindole

Hydrogen

atm.

10

25

50

75

100

125

150

175

200 $100^{\circ} \mathrm{C}$

$4.6 \mathrm{E}+07$

$1.1 E+08$

2.3E+08

$3.4 E+08$

$4.6 E+08$

$5.7 E+08$

$6.9 E+08$

$8.0 E+08$

$9.2 E+08$ $200^{\circ} \mathrm{C}$

$1.9 \mathrm{E}+05$

$4.8 E+05$

$9.7 E+05$

1. $4 E+06$

$1.9 E+06$

$2.4 E+06$

$2.9 E+06$

$3.4 E+06$

$3.9 E+06$ $300^{\circ} \mathrm{C}$

6456

16303

32626

48943

65258

81573

97888

1.1 $E+05$

1. $3 E+05$ $400^{\circ} \mathrm{C}$

178

1309

2962

4502

6022

7536

$904:$

10559

12069 
TABLE 6. Relative rates. Ratio of the full saturation pathway to the partial saturation pathway for quinoline and indole.

Decahydroquinoline path : 1,2,3,4-Tetrahydroquinoline path Hydrogen

$\begin{array}{ccccc}\text { atm. } & 100^{\circ} \mathrm{C} & 200^{\circ} \mathrm{C} & 300^{\circ} \mathrm{C} & 400^{\circ} \mathrm{C} \\ 10 & 4.6 \mathrm{E}+20 & 6.6 \mathrm{E}+08 & 13 & 5.0 \mathrm{E}-05 \\ 25 & 1.1 \mathrm{E}+23 & 1.6 \mathrm{E}+11 & 3195 & 0.012 \\ 50 & 7.1 \mathrm{E}+24 & 1.0 \mathrm{E}+13 & 2.0 \mathrm{E}+05 & 0.79 \\ 75 & 8.1 \mathrm{E}+25 & 1.2 \mathrm{E}+14 & 2.3 \mathrm{E}+06 & 9 \\ 100 & 4.6 \mathrm{E}+26 & 6.6 \mathrm{E}+14 & 1.3 \mathrm{E}+07 & 50 \\ 125 & 1.7 \mathrm{E}+27 & 2.5 \mathrm{E}+15 & 5.0 \mathrm{E}+07 & 192 \\ 150 & 5.2 \mathrm{E}+27 & 7.6 \mathrm{E}+15 & 1.5 \mathrm{E}+08 & 573 \\ 175 & 1.3 \mathrm{E}+28 & 1.9 \mathrm{E}+16 & 3.8 \mathrm{E}+08 & 1445 \\ 200 & 2.9 \mathrm{E}+28 & 4.2 \mathrm{E}+16 & 8.4 \mathrm{E}+08 & 3220\end{array}$

cis-Perhydroindole path : Incoline path

Hydrogen

$\begin{array}{ccccc}\text { atm. } & 100^{\circ} \mathrm{C} & 200^{\circ} \mathrm{C} & 300^{\circ} \mathrm{C} & 400^{\circ} \mathrm{C} \\ 10 & 7.3 \mathrm{E}+20 & 4.1 \mathrm{E}+10 & 8609 & 0.18 \\ 25 & 1.8 \mathrm{E}+23 & 1.0 \mathrm{2}+13 & 2.1 \mathrm{E}+06 & 43 \\ 50 & 1.1 \mathrm{E}+25 & 6.4 \mathrm{E}+14 & 1.3 \mathrm{E}+08 & 2736 \\ 75 & 1.3 \mathrm{E}+26 & 7.3 \mathrm{E}+15 & 1.5 \mathrm{E}+09 & 31159 \\ 100 & 7.3 \mathrm{E}+26 & 4.1 \mathrm{E}+16 & 8.6 \mathrm{E}+09 & 1.8 \mathrm{E}+05 \\ 125 & 2.8 \mathrm{E}+27 & 1.6 \mathrm{E}+17 & 3.3 \mathrm{E}+10 & 6.7 \mathrm{E}+05 \\ 150 & 8.4 \mathrm{E}+27 & 4.6 \mathrm{E}+17 & 9.8 \mathrm{E}+10 & 2.0 \mathrm{E}+06 \\ 175 & 2.1 \mathrm{E}+28 & 1.2 \mathrm{E}+18 & 2.5 \mathrm{E}+11 & 5.0 \mathrm{E}+06 \\ 200 & 4.7 \mathrm{E}+28 & 2.6 \mathrm{E}+18 & 5.5 \mathrm{E}+11 & 1.1 \mathrm{E}+07\end{array}$


obtained by Giola and Lee ${ }^{(31)}$ for quinoline HDN and those of most other researchers, notably Satterfield et al., (26-30) who do not list a pathway for HDN resulting in propylbenzene.

Giola and $\mathrm{Lee}^{(31)}$ used a sulfided $\mathrm{NiO}-\mathrm{MoO}_{3} / \gamma-\mathrm{Al}_{2} \mathrm{O}_{3}$ catalyst at $350^{\circ} \mathrm{C}$ and varied the pressure over a wide range, 10 to 150 atmospheres hydrogen. Their resulis indicated that the reaction pathway involving 2-propylaniline became more important as the pressure was decreased. They listed a complicated reaction pathway which reduced to two limiting forms. At hydrogen pressure less than 31 atmospheres the 2-propylaniline pathway dominated: at hydrogen pressure greater than 78 atmospheres the 2-propylcyclohexylamine pathway dominated.

Values for the cyclohexylamine : propylaniline ratio can be interpolated from the values listed at $300^{\circ} \mathrm{C}$ and $400^{\circ} \mathrm{C}$ listed in table 6 . The cyclohexylamine : propylaniline ratios are as follows:

$\mathrm{H}_{2}$ (atm.) Ratio cyclohexylamine rel. rate/propylaniline rel. rate

10

25

50

75

100
0.016

\section{4}

243

2770

16000

(see figure 5). The results obtained here do indeed show the dominance of the propylaniline pathway at low hydrogen pressures with conversion to the cyclohexylamine pathway as pressures approach those used by researchers other than Giola and Lee.(31)

A further literature search revealed another study of relative reactivities(67) not noted by Girgis and Gates.(5) In that study Aboul-Gheit and Abdou(67) hydrotreated a straight-run gas oil in a batch autoclave over a tungsten-nickel sulfide catalyst with an alumina support. Hydrotreating experiments were performed in the temperature range $350^{\circ} \mathrm{C}$, to $400^{\circ} \mathrm{C}$ with hydrogen pressures between 25 and 100 atmospheres. The hydrogenation products, as well as the feedstock, were analyzed for the different nitrisgen-containing compounds present to investigate their relative resistance to denitrogenation.

Table 1 of reference 67 lists the effect of hydrogenation upon the nitrogen-type distribution obtained by Aboul-Gheit and Abdou.(67) The initial gas oil contained $2175 \mathrm{ppm}$ nitrogen of which $182 \mathrm{ppm}$ were quinoline types, $42 \mathrm{ppm}$ indoles, and 779 ppm carbazoles. The original material contained no alkylamines, pyridines, or anilines. Table 1 of reference 67 shows that at $350^{\circ} \mathrm{C}$ and 100 atmospheres hydrogen 
At 10 atmospheres hydrogen pressure this path if favored by a factor of 62.5

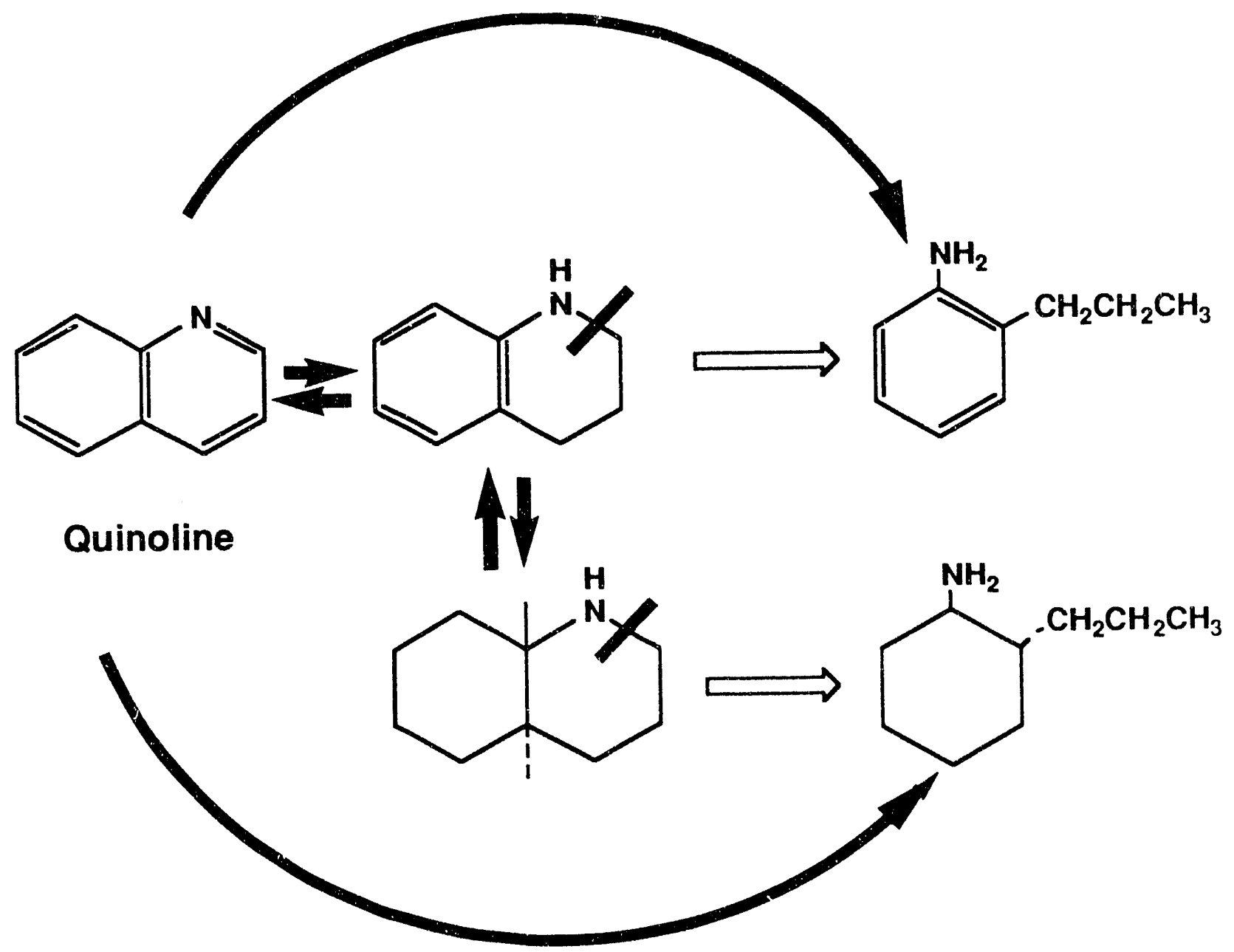

At 100 atmospheres hydrogen pressure this path if favored by a factor of 16,000 i.e., this is the SOLE product.

FIGURE 5. Examples of the effects of temperature and hydrogen pressure on the HDN of quinoline under the reaction conditions used by Giola and Lee.(31) 
pressure, 7 percent of the quinolines remained along with approximately 70 percent each for the indoles and carbazoles. The corresponding relative reactivities calculated in this research are:

$$
\text { carbazole }<\text { quinoline }<\text { indole }
$$

with values of

$$
1<110<160
$$

when normalized to allow for the differing initial concentrations. Therefore, the indole relative reactivity appears too large (but see below).

In agreement with the results obtained in this report, when the temperature was increased to $400^{\circ} \mathrm{C}$ and the pressure lowered first to 50 atmospheres of hydrogen and then 25 atmospheres of hydrogen, the amount of unconverted quinolines increased to 13 percent and 37 percent respectively. At $400^{\circ} \mathrm{C}$ and 25 atmospheres hydrogen pressure, $20 \mathrm{ppm}$ of anilines were formed for the first time. This is in excellent agreement with the results in table 6 of this report. At $400^{\circ} \mathrm{C}$ and 25 atmospheres hydrogen pressure, table 6 shows an 83 to 1 (1/0.012) preponderance for the aniline formation path over the HDN reaction path. This path is "closed" as the hydrogen pressure is increased.

In Aboul-Gheit and Abdou's(67) study, when the temperature was increased to $400^{\circ} \mathrm{C}$ and the pressure lowered first to 50 atmospheres of hydrogen and then 25 atmospheres of hydrogen, the amount of unconverted carbazoles remained approximately 70 percent, whereas the indole concentration first decreased and then increased to 200 percent of the original concentration! Indoles were formed during the experiments. Indole formation could account for the disagreement noted above for $350^{\circ} \mathrm{C}$ and 100 atmospheres hydrogen pressure.

The formation of indoles from quinolines is possible thermodynamically and can occur in the presence of a catalyst with acidic sites (i.e., a catalyst which promotes carbonium ion formation). For the reaction:

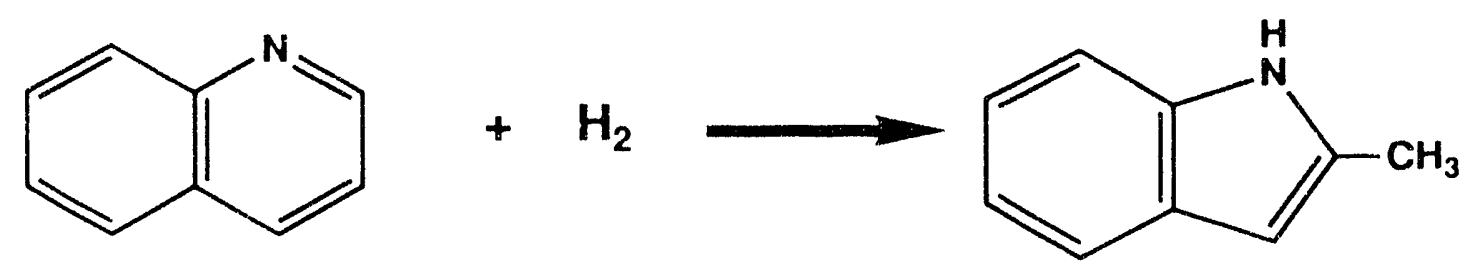

$K^{\prime}$ equals 3.6 at $400^{\circ} \mathrm{C}$ under 25 atmospheres hydrogen pressure. Calculations using the same assumptions as those delineated on page 4 of this report, give a factor of 7 for the probability of formation of 2-methylindole from quinoline under these conditions. If the pressure is increased to 100 atmospheres of hydrogen, then the probability of quinoline following this path is decreased to unity. Therefore, indole formation from 
quinolines depends on high temperature and low hydrogen pressure. This explains the results obtained by Aboul-Gheit and Abdou.(67)

\section{SUMMARY \& CONCLUSIONS}

This report outlines a new use of thermodynamic property data. The Gibbs energies of reaction obtained from thermodynamic property measurements by this Group are used to estimate, with some success, relative reactivities for aromatic organonitrogen compounds. The methodology will be expanded in a further report when data becomes available on large ring systems under study in this research program. The main conclusions of the present study can be summarized as follows:

- Thermodynamic properties (i.e., Gibbs energies of formation) are used to derive relative rates of reaction for aromatic nitrogen-containing compounds, except anilines, which reproduce literature values within one power of ten.

- Literature values were reproduced assuming the same rate constant for the ringopening step for the whole range of nitrogen-containing molecules considered.

- Relative rates of reaction are shown to be directly proportional to the concentration of hydrogenated species formed.

- One general kinetic expression can be written to account for the results obtained for both non-basic (pyrrolic) and basic (pyridinic) nitrogen-containing compounds

- The production of completely saturated ring systems (overhydrogenation) in HDN reactions, using conventional hydroprocessing, can be explained solely in terms of the thermodynamics of the system.

- The results show that the order of relative reactivities obtained are strongly dependent on the reaction temperature and hydrogen pressure. That strong dependence can account for some apparent contradictions in kinetic studies reported in the literature.

- The results for a study of the hydroprucessing of a straight-run gas oil are reproduced in this report. The formation of anilines and an increase in indole concentration above that in the original gas oil sample are explained via the thermodynamics operating in the system. 


\section{REFERENCES}

1. Fuel Science and Technology Handbook. Spreight, J. G. editor. Marcel Dekker: New York, 1990.

2. Katzer, J. R.; Sivasubramanian, R. Catal. Rev.-Sci. Eng. 1979, 20, 155.

3. Ledorix, M. J. Catalysis (London) 1985, 7, 125.

4. Ho, T. C. Catal. Rev.-Sci. Eng. 1988, 30, 117.

5. Girgis, M. J.; Gates, B. C. Ind. Eng. Chem. Res. 1991, 30, 2021.

6. Sall, J. W.; Dart, J. C. Petroleum Refining 1952, 31, 101.

7. Nat, P. J. Erdol \& Kohle, Erdgas, Petrochemie 1989, 42, 447.

8. Beaver, B. D.; Hazlett, R. N.; Cooney, J. V.; Watkins, J. M. Jr. Fuel Sci. Technol. Int. 1988, 6, 131.

9. Kollman, L. D. J. Catalysis 1977, 46, 243.

10. Stern, E. W. J. Catalysis 1979, 57, 390.

11. Mcllvried, H. G. Ind. Eng. Chem. Process Des. Dev. 1971, 10, 125.

12. Sonnemans, J.; van den Berg, G. H.; Mars, P. J. Catalysis 1973, 31, 220.

13. Satterfield, C. N.; Cocchetto, J. F. AlChE J. 1975, 21, 1107.

14. Satterfield, C. N.; Modell, M.; Wilkens, J. A. Ind. Eng. Chem. Process Des. Dev. $1980,19,154$.

15. Hanlon, R. T. Energy \& Fuels 1989, 1, 424.

16. Bhinde, M. V. Quinoline Hydrodeintrogenation Kinetics and Reaction Inhibition. PhD Thesis, University of Delaware, Newark, 1979.

17. Hartung, G. K.; Jewell, D. M.; Larson, O. A.; Flinn, R. A. J. Chem. Eng. Data $1961,6,477$.

18. Aboul-Gheit, A. K.; Aboul, I. K. J. Inst. Petroleum 1973, 59, 188.

19. Odebunmi, E. O.; Oliis, D. F. J. Catalysis 1983, 80, 76.

20. Olive, J.-L.; Biyoko, S.; Moulinas, C.; Geneste, P. Applied Catalysis 1985, 19, 165.

21. Shaw, J. E.; Stapp, P. R. J. Heterocyclic Chem. 1987, 24, 1477.

22. Skala, D. U.; Saban, M. D.; Jovanovia, J. A.; Meyn, V. W.; Rahimian, I. G.-H. Ind. Eng. Chem. Res. 1988, 27, 1186.

23. Cocchetto, J. F.; Satterfield, C. N. Ind. Eng. Chem. Process Des. Dev. 1975, 15, 272.

24. Satterfield, C. N.; Modell, M.; Hites, R. A.; Declerck, C. J. Ind. Eng. Chem. Process Des. Dev. 1976, 17, 141.

25. Shih S. S.; Katzer, J. R.; Kwart, H.; Stiles, A. B. Prepr.-Am. Chem. Soc. Div. Pet. Chem. 1977, 22, 219.

26. Cocchetto, J. F.; Satterfield, C. N. Ind. Eng. Chem. Process Des. Dev. 1981, 20, 49.

27. Satterfield, C. N.; Cocchetto, J. F. Ind. Eng. Chem. Process Des. Dev. 1981, 20, 53.

28. Satterfield, C. N.; Gültekin, S. Ind. Eng. Chem. Process Des. Dev. 1981, 20, 62.

29. Yang, S. H.; Satterfield, C. N. Ind. Eng. Chem. Process Des. Dev. 1984, 23, 20.

30. Satterfield, C. N.; Yang, S. H. Ind. Eng. Chem. Process Des. Dev. 1984, 23, 11.

31. Giola, F.; Lee, V. Ind. Eng. Chem. Process Des. Dev. 1986, 25, 918.

32. Satterfield, C. N.; Smith, C. M. Ind. Eng. Chem. Process Des. Dev. 1986, 25, 942.

33. Schlatter, J. C.; Oyama, S. T.; Metcalfe, J. E. III; Lambert, J. M. Jr.; Ind. Eng. Chem. Res. 1988, 27, 1648.

34. Shaw, J. E. Fuel 1988, 67, 1706.

35. Collins, D. J.; Llody, E. C. Applied Catalysis 1988, 41, 81.

36. Yu, C-y.; Hatcher, W. J. Jr.; Bertach, W. Ind. Eng. Chem. Res. 1989, 29, 13.

37. Curtis, C. W.; Cahela, D. R. Energy \& Fuels 1989, 3, 168.

38. Gültekin, S.; Khaleeg, M.; Al-Saleh, M. A. Ind. Eng. Chem. Res. 1989, 28, 729. 
39. Nagai, M.; Masunaga, T. Fuel 1988, 67, 771.

40. Shabtai, J.; Yeh, G. J. C.; Russel, C.; Oblad, A. G. Ind. Eng. Chem. Res. 1989, 28, 139.

41. Moreau, C.; Durand, R.; Zmimita, N.; Geneste, P. J. Catalysis 1988, 112, 411.

42. Shabati, J.; Veluswamy, L.; Oblad, A. G. Prepr.-Am. Chem. Soc. Div. Fuel Chern. $1978,23,114$.

43. Malakani, K.; Magnoux, P.; Perot, G. Applied Catalysis 1987, 30, 371.

44. Sarbak, Z. React. Kinet. Catal. Lett. 1986, 32, 435.

45. Nagai, M.; Sawahiraki, K.; Kabe, T. Nippon Kagaka Kaishi 1980, p. 69.

46. Nagai, M.; Masunaga, T; Hana-oka, N. Energy \& Fuels 1988, 2, 645.

47. Yeh, Ji-C. Hydrodenitrogenation Studies of Condensed Carbocyclic-NHeterocyclic Compounds and of an SRC-II Distillate PhD Thesis. University of Utah. March 1985.

48. Polinszky, A.; Gadgil, K.; Schon, M.; Schulz, H. Hungarian. J. Ind. Chem. Vesz. $1988,16,211$.

49. Kerr, J. A. Ann. Rep. Chem. Soc. (A) 1967, 64, 73..

50. Steele, W. V.; Chirico, R. D.; Collier, W. B.; Harrison, R. H.; Gammon, B. E. Assessment of Thermodynamic Data and Needs, Including Their Economic Impact, for Development of New Fossil Fuel Refining Processes. NIPER-159. Published by DOE Fossil Energy, Bartlesville Project Office. Available from NTIS Report No. DE-86000298, June 1986.

51. Steele, W. V.; Chirico, R. D.; Collier, W. B.; Hossenlopp, I. A.; Nguyen, A.; Strube, M. M. Thermochemical and Thermophysical Properties of Organic Nitrogen Compounds Found in Fossil Materials. NIPER-188. Published by DOE Fossil Energy, Bartlesville Project Office. Available from NTIS Report No. DE87001204, November 1986.

52. Steele, W. V.; Archer, D. G.; Chirico, R. D.; Strube, M. M. Comparison of the Thermodynamics of Nitrogen and Sulfur Removal in Heavy Oil Upgrading. Part 1. Acyclic and Monocyclic Compounds NIPER-264. July 1987.

53. Steele, W. V.; Archer, D. G.; Chirico, R. D.; Collier, W. B.; Gammon, B. E.; Hossenlopp, I. A.; Nguyen, A.; Smith, N. K. The Thermodynamic Properties of Quinoline and Isoquinoline. NIPER-301. Published by DOE Fossil Energy, Bartlesville Project Office. Available from NTIS Report No. DE-88001218, November 1987.

54. Messerly, J. F.; Todd, S. S.; Finke, H. L.; Good, W. D.; Gammon, B. E. J. Chem. Thermodynamics 1988, 20, 209.

55. Steele, W. V.; Archer, D. G.; Chirico, R. D.; Collier, W. B.; Hossenlopp, I. A.; Nguyen, A.; Smith, N. K.; Garnmon, B. E. J. Chem. Thermodynamics 1988, 20 , 1233.

56. Steele, W. V.; Chirico, R. D.; Hossenlopp, I. A.; Nguyen, A. The Thermodynamic Properties of the Five Benzoquinolines. NIPER-337. April 1988. Published by DOE Fossil Energy, Bartlesville Project Office. Available from NTIS Report No. DE-88001240, October 1988.

57. Steele, W. V.; Chirico, R. D.; Hossenlopp, I. A.; Nguyen, A.; Smith, N. K.; Gammon, B. E. J. Chem. Thermodynamics 1989, 21, 81.

58. Steele, W. V.; Chirico, R. D.; Hossenlopp, I. A.; Nguyen, A. Smith, N. K. The Thermodynamic Properties of 1,2,3,4- and 5,6,7,8-Tetrahydroquinolines. NIPER-399. Published by DOE Fossil Energy, Bartlesville Project Office. Available from NTIS, Report No. 89000729, December 1988.

59. Steele, W. V.; Chirico, R. D.; Hossenlopp, I. A.; Nguyen, A.; Smith, N. K.; Gammon, B. E. J. Chem. Thermodynamics 1989, 21, 1121.

60. Steele, W. V.; Chirico, R. D. Thermodynamics and the Hydrodenitrogenation of Indole. NIPER-415. Published by DOE Fossil Energy, Bartlesville Project Office. Available from NTIS Report No. DE-89000751, June 1989. 
61. Steele, W. V.; Chirico, R. D.; Nguyen, A.; Knipmeyer S. E. The Thermodynamic Properties of 2-Methylaniline and trans-(R,S)-Decahydroquinoline. NIPER459. Published by DOE Fossil Energy, Bartlesville Project Office. Available from NTIS, Report No. 90000216 November 1989.

62. Steele, W. V.; Chirico, R. D. Thermodynamics of the Hydrodenitrogenation of Quinoline. NIPER-468. Published by DOE Fossil Energy, Bartlesville Project Office. Available from NTIS, Report No. 90000245, June 1990.

63. Steele, W. V.; Knipmeyer S. E.; Chirico, R. D. Critical Property and HighTemperature Heat-Capacity Measurements on Quinoline and 5,6,7,8Tetrahydroquinoline. NIPER-469. Published by DOE Fossil Energy, Bartlesville Project Office. Available from NTIS, Report No. 90000246, June 1990.

64. Steele, W. V.; Chirico, R. D.; Knipmeyer S. E.; Nguyen, A. The Thermodynamic Properties of 2-Aminobiphenyl (An Intermediate in the Carbazole/Hydrogen Reaction Network). NIPER-482. Published by DOE Fossil Energy, Bartlesville Project Office. Available from NTIS, Report No. 91002209 January 1991.

65. Steele, W. V.; Knipmeyer S. E.; Nguyen, A.; Chirico, R. D. The Thermodynamic Properties of 9-Methylcarbazole and 1,2,3,4-Tetrahydro-9-Methylcarbazole. NIPER-520. Published by DOE Fossil Energy, Bartlesville Project Office. Available from NTIS, Report No. 91002235 April 1991.

66. Steele, W. V.; Chirico, R. D. Thermodynamics of the Hydrodenitrogenation of Carbazole. NIPER-544. Published by DOE Fossil Energy, Bartlesville Project Office. Available from NTIS, Report No. 91002255 October 1991.

67. Aboul-Gheit, A. K.; Aboul, I. K. J. Inst. Petroleum 1972, 58, 305. 

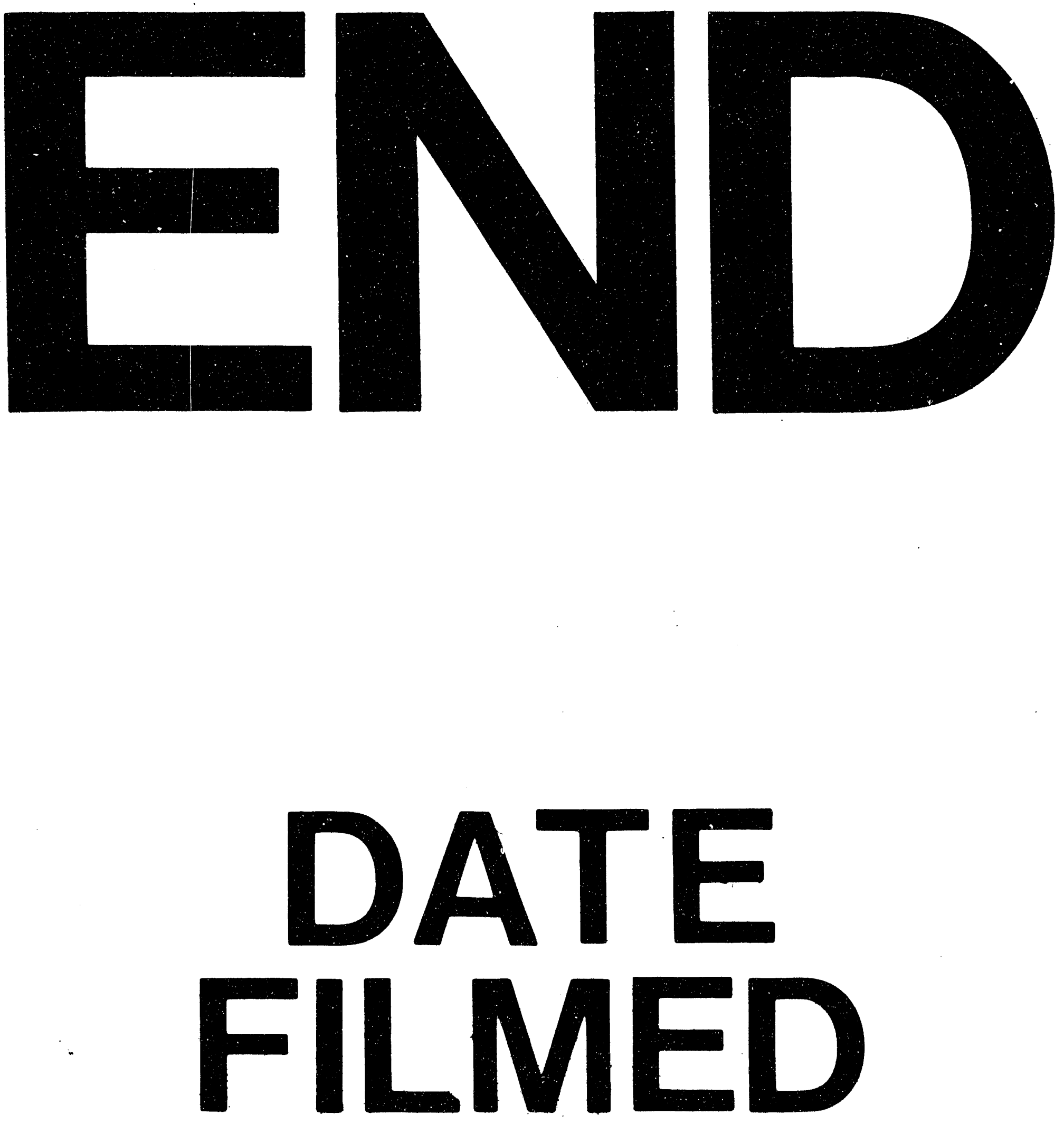

I

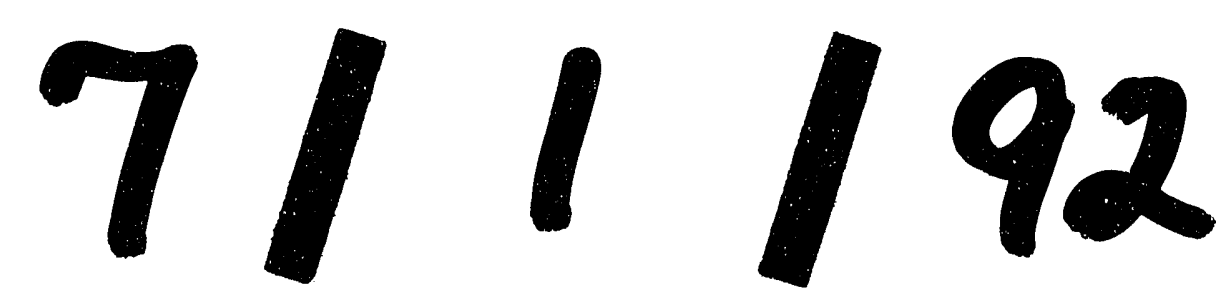


